\title{
Bioreduction of Idarubicin and Formation of ROS Responsible for DNA Cleavage by NADPH-Cytochrome P450 Reductase and its Potential Role in the Antitumor Effect
}

\author{
Haydar Çelik ${ }^{1,2}$ and Emel Arinç ${ }^{1}$ \\ ${ }^{1}$ Biochemistry Graduate Programme and Department of Biological Sciences, Middle East Technical University, 06531 \\ Ankara, Turkey. ${ }^{2}$ Department of Food Engineering, Institute of Natural and Applied Sciences, Erciyes University, \\ 38039 Kayseri, Turkey.
}

Received July 11, 2008; Revised November 21, 2008; Accepted December 23, 2008, Published December 30, 2008.

\begin{abstract}
Purpose. Idarubicin is a clinically effective synthetic anthracycline analog used in the treatment of several human neoplasms. Anthracyclines have the potential to undergo bioactivation by flavoenzymes to free radicals and thus exert their cytotoxic actions. In this study, our main objective was to investigate the possible involvement of NADPH-cytochrome P450 reductase in the bioreductive activation of idarubicin to DNA-damaging species. Methods. A pBR322 plasmid DNA damage assay was used as a sensitive method for detecting strand breaks in DNA exposed to idarubicin in the presence of P450 reductase and cofactor NADPH under various incubation conditions. In addition, the rates of idarubicin reduction by $\mathrm{P} 450$ reductases purified from phenobarbital-treated rabbit liver, beef liver and sheep lung microsomes were determined by measuring NADPH oxidation at $340 \mathrm{~nm}$. Results. The plasmid DNA experiments demonstrated that idarubicin could undergo bioreduction by $\mathrm{P} 450$ reductase with the resulting formation of DNA strand breaks. The antioxidant enzymes SOD and catalase, and hydroxyl radical scavengers, DMSO and thiourea, afforded significant levels of protection against idarubicininduced DNA strand breaks. These findings suggested that DNA damage by idarubicin occurs through a mechanism which involves its redox cycling with $\mathrm{P} 450$ reductase to generate reactive oxygen species (ROS). The extent of DNA damage by idarubicin was found to increase with increasing concentrations of drug or enzyme as well as with increasing incubation time. The capacity of idarubicin to induce DNA damage under above incubation conditions was compared with that of a model compound, mitomycin C. Finally, enzyme assays carried out with purified P450 reductases revealed that idarubicin exhibited about two-fold higher rate of reduction than mitomycin C. Conclusion. Our findings
\end{abstract}

implicated bioreduction of idarubicin by $\mathrm{P} 450$ reductase and subsequent redox cycling under aerobic conditions as being one mode of idarubicin action potentially contributing to its antitumor effect.

\section{INTRODUCTION}

Anthracyclines represent a large group of clinically effective quinone-containing antibiotics which are widely used in anticancer chemotherapy for the treatment of solid tumors and hematological malignancies including lymphomas, acute lymphocytic as well as myelocytic leukemias $(1,2)$. However, the clinical utility of these agents is severely limited by dosedependent cardiotoxicity (1). A great number of analogues (approximately 2000 compounds) chemically related to the parent anthracyclines, therefore, have been synthesized and tested in experimental tumor models in an approach to obtain better anthracycline analogs with improved antineoplastic activities and less cardiotoxic properties $(1,3)$. Among these analogs, however, only a few have reached clinical trials and approved for clinical use. One such analog is idarubicin (4-demethoxydaunorubicin), which has been approved by the US FDA in 1990 for the treatment of acute myelogenous leukemia (4).

The chemical structure of idarubicin corresponds to that of the parent drug daunorubicin with the exception of the absence of methoxy group at C-4 position of the D ring in the aglycone moiety. This minor modification of the molecule, however, leads to major changes in the pharmacological properties of the drug (4).

Corresponding Author: Professor Emel Arinç, Biochemistry Graduate Programme and Department of Biological Sciences, Middle East Technical University, 06531 Ankara, Turkey, E-mail: earinc@metu.edu.tr 
Idarubicin is more lipophilic than its parent drug which leads to a better oral bioavailability and significantly enhanced cellular uptake $(5,6)$. The higher lipophilicity of the drug allows it to accumulate faster in the nuclei and to bind DNA with higher affinity which consequently results in a greater cytotoxicity compared to daunorubicin (4). The major metabolite of idarubicin, idarubicinol, shows equipotent cytotoxic activity as the parent compound and a much greater activity than the other anthracycline alcohol metabolites. The ability of idarubicin and mainly idarubicinol to cross the blood-brain barrier makes the drug particularly important for clinical use $(4,6)$. Idarubicin appears to be less cardiotoxic than other anthracyclines and overcomes, at least partially, multidrug resistance $(4,5)$.

Although anthracycline anticancer drugs have been used extensively and for a long time in the clinic, a controversy still remains on their exact mechanisms of action. Several mechanisms have been postulated to account for the antitumor effects of these agents. These include intercalation into DNA resulting in inhibition of DNA biosynthesis, free radical generation with induction of DNA damage or lipid peroxidation, alkylation of DNA and DNA cross-linking, interference with DNA unwinding or DNA strand separation and helicase activity, direct membrane effects, initiation of DNA damage via inhibition of topoisomerase II and induction of apoptosis (for a review, see reference 7). Among these proposed mechanisms, free radical generation and subsequent redox cycling has been suggested as having an important contributing role on the effectiveness of anthracycline chemotherapy agents (2,8-10). Free radical generation by anthracyclines involves their bioreductive activation by cellular oxidoreductases (11). The one-electron reductase NADPH-cytochrome P450 reductase, in particular, is proposed to play a major role in this process.

The studies on the molecular mechanisms of action and bioreductive activation of anthracyclines have been generally conducted with natural anthracycline doxorubicin. A large number of articles, for example, have been published considering the bioreduction of doxorubicin by various purified enzymes (see references 2,3). The semisynthetic drug idarubicin has unique features with respect to its oral bioavailability, pharmacokinetics, toxicity and antitumor activity that distinguish it from other natural anthracyclines. However, despite its many advantageous properties over other anthracyclines, to our knowledge, no report on the bioreductive activation of idarubicin by purified NADPH-cytochrome P450 reductase has appeared. This is particularly important, given the fact that modification or removal of functional groups of a drug may affect its physicochemical and biological properties including its binding affinity to cellular enzymes.

In the present study, we utilized purified enzymes in order to examine the reduction of idarubicin by NADPH cytochrome P450 reductase, and determined whether this reduction results in the formation of DNA-damaging species by employing a pBR322 plasmid DNA damage assay. The in vitro plasmid DNA damage assay used in this study is a very useful and sensitive method for detecting strand breaks in plasmid DNA exposed to various damaging agents. It has been used effectively by researchers as a method for evaluating the role of different reductive enzymes on the bioactivation of various anticancer drugs and compounds (12-17). In order to investigate the mechanism of DNA damage by idarubicin, we employed antioxidant enzymes superoxide dismutase (SOD) and catalase as well as scavengers of hydroxyl radicals $\left(\mathrm{OH}^{\prime}\right)$, dimethyl sulfoxide (DMSO) and thiourea. Their protective effects against strand breaks may indicate whether reactive oxygen species (ROS) produced during redox cycling of idarubicin with P450 reductase can play a role in the DNAdamaging activity of this anticancer drug. In this study, we also tried to characterize the DNAdamaging potential of idarubicin with respect to increasing concentrations of drug or enzyme as well as increasing incubation time using the above method. All these results obtained from above studies were compared with those obtained using a model compound, mitomycin $\mathrm{C}$, a well-known redox cycling quinone with cytochrome P450 reductase, by performing the experiments under the same reaction conditions as with idarubicin.

\section{MATERIALS AND METHOD}

\section{Chemicals}

Idarubicin hydrochloride, cytochrome c, phenylmethane sulfonyl fluoride (PMSF), $\varepsilon^{-}$ amino caproic acid ( $\varepsilon$-ACA), bovine liver catalase, thiourea, superoxide dismutase (SOD) 
from bovine erythrocytes and bovine serum albumin (BSA) were purchased from SigmaAldrich Chemical Company, Saint Louis, Missouri, USA. Mitomycin C was obtained from Kyowa Hakko Kogyo Co., Ltd., Tokyo, Japan. pBR322 plasmid DNA was purchased from Fermentas International Inc., Ontario, Canada. All other chemicals used were obtained from commercial sources at the highest grade of purity available.

\section{Preparation of microsomes and enzyme purification}

Sheep lung microsomes were prepared by differential centrifugation as previously described (18) except that homogenization solution contained $2 \mathrm{mM}$ EDTA, $0.25 \mathrm{mM}$-ACA, 0.1 $\mathrm{mM}$ PMSF in $1.15 \% \mathrm{KCl}$. The prepared microsomes were stored at $-80^{\circ} \mathrm{C}$ in a deep freezer until used for purification studies. NADPH-cytochrome P450 reductase from sheep lung microsomes was purified by slight modifications of the already existing methods developed in our laboratory $(19,20)$. Briefly, the procedure involved anion exchange chromatography of the detergent solubilized microsomes on two successive DEAE-cellulose columns followed by affinity chromatography of the partially purified $\mathrm{P} 450$ reductase on adenosine 2', 5'-diphosphate-Sepharose 4B column. Further purification and concentration of the enzyme was achieved on a final hydroxylapatite column. Besides sheep lung P450 reductase, cytochrome P450 reductases purified from beef liver and phenobarbital-induced rabbit liver microsomes were also used in this study. Beef liver NADPHcytochrome $\mathrm{P} 450$ reductase was purified to apparent homogeneity from the detergent solubilized microsomes according to the method described by Arinç and Çelik (21). Phenobarbital treatment of rabbits and preparation of liver microsomes were performed as described previously (18). NADPH-cytochrome P450 reductase of phenobarbital-induced rabbit liver microsomes was purified by a slight modification of the above described procedures. The purity of the final purified enzyme preparations were analyzed by sodium dodecyl sulfatepolyacrylamide gel electrophoresis (22). It was found that all the purified enzymes were homogenous and gave a single protein band on SDS-PAGE. Protein concentrations were determined by the method of Lowry et al. (23) utilizing bovine serum albumin as the standard.

NADPH-cytochrome $\mathbf{P 4 5 0}$ reductase activity assay

NADPH-cytochrome P450 reductase activity was measured spectrophotometrically by measuring the rate of reduction of artificial substrate, cytochrome $c$, at $550 \mathrm{~nm}$ at $25^{\circ} \mathrm{C}$ as described by Masters et al. (24). The reaction mixture contained $0.3 \mathrm{M}$ potassium phosphate buffer, $\mathrm{pH}$ 7.7, containing $80 \mathrm{nmol}$ cytochrome $c, 130 \mathrm{nmol}$ $\mathrm{NADPH}$ and appropriate amounts of enzyme preparations in a final volume of $0.8 \mathrm{ml}$. The enzyme activities were calculated using the extinction coefficient of $19.6 \mathrm{mM}^{-1} \cdot \mathrm{cm}^{-1}$ for the difference in absorbance between the reduced minus the oxidized form of cytochrome $c$ at 550 $\mathrm{nm}$ as described by Yonetani (25). One unit of reductase is defined as the amount of enzyme catalyzing the reduction of $1.0 \mu$ mole of cytochrome $c$ per minute under above conditions.

\section{Reduction of idarubicin and mitomycin $\mathrm{C}$ as measured by NADPH oxidation}

The initial rates of idarubicin and mitomycin $\mathrm{C}$ reduction by purified NADPH-cytochrome $\mathrm{P} 450$ reductases were determined by measuring druginduced NADPH oxidation at $340 \mathrm{~nm}$ in a Hitachi U-2800 double beam spectrophotometer. All reactions were performed at $25^{\circ} \mathrm{C}$ under aerobic conditions. The reaction mixture contained $0.3 \mathrm{M}$ potassium phosphate buffer, $\mathrm{pH} 7.7,0.1 \mathrm{mM}$ EDTA, $\mathrm{pH}$ 7.7, $25 \mu \mathrm{M}$ of either drug, appropriate amounts of purified cytochrome $\mathrm{P} 450$ reductases and $0.1 \mathrm{mM}$ NADPH in a final volume of $1.0 \mathrm{ml}$. The reactions were initiated by the addition of cofactor NADPH. Reduction of drugs was measured by following NADPH consumption at $340 \mathrm{~nm}$ using an extinction coefficient of 6.22 $\mathrm{mM}^{-1} \cdot \mathrm{cm}^{-1}$. Control incubations were carried out by performing identical incubations without enzyme or either drug. Reaction rates were corrected by subtracting the very low rates of $\mathrm{NADPH}$ consumption by the purified P450 reductases measured in the absence of drugs.

\section{DNA strand cleavage assay}

DNA strand breakage was detected by the method based on the conversion of supercoiled form of 
plasmid DNA (SC, Form I) to the open (nicked) circular form (OC, Form II) and their differential mobility on agarose gel as reported previously by others $(12,13,15)$. The experiments were performed in a volume of $60 \mu$ reaction mixture containing supercoiled pBR322 (1.0 $\mu \mathrm{g})$, idarubicin $(100 \mu \mathrm{M})$ or mitomycin $\mathrm{C}(100 \mu \mathrm{M})$, purified sheep lung NADPH-cytochrome P450 reductase $(0.1 \mu \mathrm{g})$, NADPH $(2 \mathrm{mM})$ and $100 \mathrm{mM}$ sodium phosphate buffer, $\mathrm{pH}$ 7.4. The samples were incubated at $37^{\circ} \mathrm{C}$ for 30 minutes. Untreated pBR322 plasmid-alone and reaction mixtures in which one of the reaction components omitted were included as controls in each run of gel electrophoresis. For hydroxyl radical $(\mathrm{OH})$ induced DNA damage, a typical $\mathrm{OH}^{-}$generating system consisting of $10 \mu \mathrm{M}$ ferric chloride, 20 $\mu \mathrm{M}$ EDTA and $1 \mathrm{mM}$ ascorbate was employed (14). After incubating the samples at $37^{\circ} \mathrm{C}$ for 30 minutes under dimmed light, $5 \mu \mathrm{l}$ of loading buffer $(0.25 \%$ bromophenol blue, $0.5 \%$ SDS, $60 \%$ glycerol and $5 \mathrm{mM}$ EDTA) was mixed with $20 \mu \mathrm{l}$ aliquots of reaction mixtures. The samples were then analyzed by electrophoresis on a $1 \%$ agarose horizontal slab gel containing final concentration of $0.5 \mu \mathrm{g} / \mathrm{ml}$ of ethidium bromide in Tris-borate buffer (45 mM Tris-borate, $1 \mathrm{mM}$ EDTA). Gels were photographed using a computer-based gel imaging instrument system (Infinity 3000-CN3000 darkroom) (Vilber Lourmat, Marne-laVallee Cedex 1, France) with Infinity-Capt Version 12.9 software, and DNA damage was quantified using Scion Image Version Beta 4.0.2 software. A correction factor of 1.22 was applied to values obtained from densitometric analysis of the bands corresponding to the supercoiled form of plasmid DNA to account for decreased binding of ethidium bromide into this form as compared to others (12).

DNA damage was expressed as \% OCDNA which was calculated by using the below formula (26): \% OC-DNA = (open circular DNA / total DNA) x 100. The protective effects of ROS scavengers against $\mathrm{OH}-$, idarubicin- and mitomycin C-induced DNA strand breaks were expressed as protection (\%), and calculated as described by Ashikaga et al. (26) which is given at the top of the next page.

\section{RESULTS}

Induction of DNA damage during bioreductive activation of idarubicin by purified sheep lung P450 reductase

The double stranded pBR322 plasmid DNA in its native state exists in a compact supercoiled form (SC, form I) which is converted to nicked circular or open circular DNA (OC, form II) upon singlestrand cleavage. When double-strand breaks or two opposing single-strand breaks in close proximity are formed, the supercoiled circular DNA molecule is converted into linear form (Form III). As the intensity of damage increases, the DNA molecule is broken down ultimately into small DNA fragments which results in the complete degradation of pBR322 DNA. These three forms of plasmid DNA have different electrophoretic mobilities on the agarose gel due to their different tertiary structures. The supercoiled DNA moves faster in the gel compared to the open circular form which has a reduced electrophoretic mobility, whereas, linear form of plasmid DNA migrates as a single band between the bands corresponding to supercoiled and open circular forms of plasmid DNA. The conversion of supercoiled DNA to open circular form and their subsequent separation by agarose gel electrophoresis was used, therefore, as a sensitive method in this study to examine whether idarubicin could undergo bioreductive activation by purified sheep lung P450 reductase to DNAdamaging species, and if so, to investigate the possible involvement of ROS in the formation of DNA strand breaks as a consequence of P450 reductase-catalyzed bioactivation of idarubicin.

As shown in Figure 1, incubation of plasmid DNA with idarubicin in the presence of purified sheep lung P450 reductase and cofactor NADPH under aerobic conditions resulted in loss in the intensity of bands corresponding to the supercoiled form with concomitant increase in those associated with the open circular form (lanes 6 and 10). Control incubations in which either enzyme, cofactor NADPH or drug were omitted produced no DNA strand breaks over plasmid-alone control (lanes 7, 8 and 9) indicating that the purified sheep lung P450 reductase catalyzes the bioreductive activation of idarubicin to DNA-damaging species. 
Protection $(\%)=\left(1-\frac{\% \text { OC-DNA (in the presence of scavenger) }-\% \text { OC-DNA (untreated) }}{{ }^{a}}\right) \times 100$

a \% OC-DNA for untreated pBR322 plasmid DNA-alone (control).

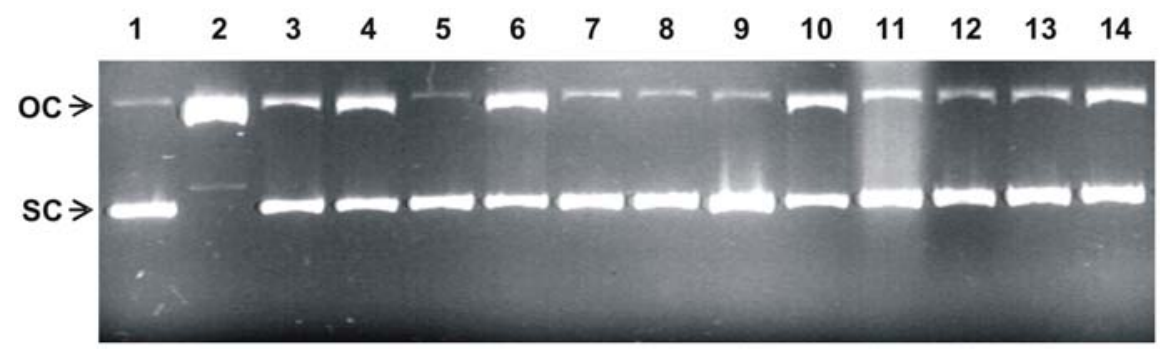

Figure 1. Agarose gel electrophoresis showing the protective effects of radical scavengers against plasmid DNA strand breaks generated during purified sheep lung NADPH-cytochrome P450 reductase (P450R)-catalyzed reductive activation of idarubicin in the presence of cofactor NADPH. Supercoiled pBR322 DNA $(1.0 \mu \mathrm{g})$ was incubated for 30 minutes at $37^{\circ} \mathrm{C}$ in the presence of P450R $(0.1 \mu \mathrm{g})$, NADPH $(2 \mathrm{mM})$ and idarubicin $(100 \mu \mathrm{M})$ with various radical scavengers at indicated concentrations in a final volume of $60 \mu 1$ reaction mixture as described in "Materials and Methods". Agarose gel electrophoresis, lane 1, plasmid DNA control; lane 2, plasmid DNA + hydroxyl radical generating system (10 $\mu \mathrm{M}$ ferric chloride-20 $\mu \mathrm{M}$ EDTA-1 mM ascorbate); lane 3, plasmid DNA + hydroxyl radical generating system $+50 \mathrm{mM}$ DMSO; lane 4, plasmid DNA + hydroxyl radical generating system $+10 \mathrm{mM}$ thiourea; lane 5, plasmid DNA + idarubicin only; lane 6, complete system (plasmid DNA + idarubicin + P450R + NADPH); lane 7, no P450R control (plasmid DNA + idarubicin + NADPH); lane 8, no NADPH control (plasmid DNA + idarubicin + P450R); lane 9, no idarubicin control (plasmid DNA + P450R + NADPH); lane 10, complete system (plasmid DNA + idarubicin + P450R + NADPH); lane 11, complete system + SOD (42 units); lane 12, complete system + catalase (42 units); lane 13, complete system $+50 \mathrm{mM}$ DMSO; lane 14, complete system $+10 \mathrm{mM}$ thiourea.

$\mathrm{SC}$, supercoiled (form I); OC, open circular (form II).

In order to investigate the mechanism of DNA damage by idarubicin and the identity of radical species involved in this process, antioxidant enzymes, SOD and catalase, and scavengers of hydroxyl radicals, DMSO and thiourea, were employed. For this purpose, first of all, the effects of hydroxyl radicals generated via a typical $\mathrm{OH}^{\circ}$ generating system (ferric chlorideEDTA-ascorbate) on the induction of DNA damage were demonstrated. As shown in Figure 1 , exposure of the pBR322 plasmid DNA to $\mathrm{OH}^{\circ}$ generating system lead to a complete conversion of supercoiled form into open circular and linear forms (lane 2). The yield of $\mathrm{OH}^{-}$-induced DNA strand breaks was found to be reduced by the addition of DMSO and thiourea (lanes 3 and 4). It was found that thiourea at a concentration of 10 $\mathrm{mM}$ was less protective than DMSO at $50 \mathrm{mM}$ concentration in preventing $\mathrm{OH}^{-}$-induced DNA damage. While thiourea provided a $65 \%$ protection against $\mathrm{OH}^{-}$-induced DNA strand breaks, treatment of plasmid DNA with DMSO resulted in a $86 \%$ reduction in strand scission (Table 1).

Figure 1 also demonstrates that DNA strand breaks produced as a consequence of $\mathrm{P} 450$ reductase-catalyzed bioreductive activation of idarubicin were significantly inhibited by the treatment of pBR322 plasmid DNA with DMSO and thiourea (lanes 13 and 14). While $50 \mathrm{mM}$ DMSO produced a $71 \%$ reduction in DNA strand breaks, treatment of plasmid DNA with $10 \mathrm{mM}$ thiourea lead to a $58 \%$ protection (Table 1). Similarly, both SOD and catalase were found to be very effective in protecting DNA against strand scission induced by idarubicin (Figure 1, lanes 11 and 12). Treatment of pBR322 plasmid DNA with SOD and catalase at 42.0 units per assay concentrations provided 86 and $76 \%$ protections against idarubicin-induced singlestrand breaks, respectively (Table 1).

The above plasmid DNA experiments were also repeated under the same reaction conditions using mitomycin $\mathrm{C}$ and the results were compared. We have chosen mitomycin $\mathrm{C}$ as 
a model compound, since it is a well-known redox cycling quinone-containing anticancer drug that produces oxygen radicals in the presence of cytochrome P450 reductase (27). Figure 2 and Table 1 demonstrate that essentially similar results were obtained when mitomycin $\mathrm{C}$ was used instead of idarubicin.

\section{Comparison of DNA-damaging potentials of idarubicin and mitomycin $C$ in the presence of purified sheep lung $\mathbf{P 4 5 0}$ reductase}

In order to evaluate the in vitro capacity of idarubicin to undergo bioreduction by cytochrome P450 reductase, and thus to induce DNA damage, the effects of increasing incubation time, drug concentration and enzyme amount on the generation of single-strand DNA breaks were examined. Typical results demonstrating the effects of increasing incubation time, drug concentration and enzyme amount on the generation of idarubicin-induced DNA strand breaks in the presence of purified sheep lung P450 reductase are presented in Figure 3, Figure 4 and Figure 5. It was shown that the degree of DNA damage increased as a function of increasing incubation time (5-90 minutes) (Figure
3) or drug concentration $(1-400 \mu \mathrm{M})$ (Figure 4) as well as with increasing amounts of enzyme added (0.025-1.25 $\mu \mathrm{g}$ ) (Figure 5). There was no DNA damage when NADPH, enzyme or drug were omitted from incubation mixtures (Figures 3, 4 and 5).

The potential of idarubicin to generate DNA strand breaks following bioreductive activation by cytochrome $\mathrm{P} 450$ reductase was then compared with mitomycin $\mathrm{C}$ as determined by the assessment of DNA damage under above conditions (for mitomycin $\mathrm{C}$, agarose gels not shown). Table 2 shows the comparison of idarubicin- and mitomycin C-induced DNA damage at the same drug concentrations with respect to increasing incubation time. Aerobic incubation of plasmid DNA with idarubicin for 30 minutes in the presence of purified sheep lung P450 reductase and cofactor NADPH resulted in about $40 \%$ increase in OC form over control, whereas incubation for 90 minutes produced about $75 \%$ increase over control (Table 2 and Figure 3). The time-course experiment for the generation of DNA strand breaks induced by mitomycin $\mathrm{C}$ produced essentially similar results with idarubicin (Table 2).

Table 1. Protective effects of radical scavengers against hydroxyl radical $\left(\mathrm{OH}^{\circ}\right)$-, idarubicin- and mitomycin $\mathrm{C}$-induced DNA strand breaks.

\begin{tabular}{|c|c|c|}
\hline Treatment & \multicolumn{2}{|c|}{$\begin{array}{c}\text { Hydroxyl radical }(\mathrm{OH})- \\
\text { induced }\end{array}$} \\
\hline \multirow{3}{*}{$\begin{array}{l}\text { pBR322 + OH radical gen. sys. }{ }^{\text {b }}+\text { DMSO }(50 \mathrm{mM}) \\
\text { pBR322 + OH radical gen. sys. }+ \text { thiourea }(10 \mathrm{mM})\end{array}$} & \multirow{2}{*}{\multicolumn{2}{|c|}{$\begin{array}{l}85.9 \\
64.7\end{array}$}} \\
\hline & & \\
\hline & $\begin{array}{l}\text { Idarubicin- } \\
\text { induced }\end{array}$ & $\begin{array}{l}\text { Mitomycin C- } \\
\text { induced }\end{array}$ \\
\hline Complete system $^{\mathrm{c}}+$ SOD (42 units) & 85.7 & 86.8 \\
\hline Complete system + catalase (42 units) & 75.6 & 80.3 \\
\hline Complete system + DMSO (50 mM) & 71.4 & 85.9 \\
\hline Complete system + thiourea $(10 \mathrm{mM})$ & 57.5 & 63.6 \\
\hline
\end{tabular}

Experimental conditions are described in detail under "Materials and Methods".

a Calculations for protection (\%) values are described in "Materials and Methods".

${ }^{\mathrm{b}}$ Hydroxyl radical $\left(\mathrm{OH}^{\prime}\right)$ generating system consists of $10 \mu \mathrm{M}$ ferric chloride-20 $\mu \mathrm{M}$ EDTA$1 \mathrm{mM}$ ascorbate.

${ }^{c}$ Complete system consists of pBR322 plasmid DNA $(1.0 \mu \mathrm{g})+$ idarubicin $(100 \mu \mathrm{M})$ or mitomycin $\mathrm{C}(100 \mu \mathrm{M})+$ purified sheep lung NADPH-cytochrome P450 reductase $(0.1 \mu \mathrm{g})$

+ NADPH $(2 \mathrm{mM})$ in a final volume of $60 \mu 1$ reaction mixture. 


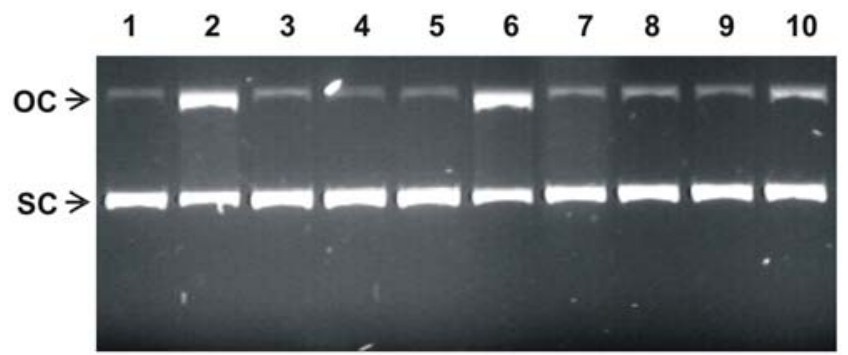

Figure 2. Agarose gel electrophoresis showing the protective effects of radical scavengers against plasmid DNA strand breaks generated during purified sheep lung NADPH-cytochrome P450 reductase (P450R)-catalyzed reductive activation of mitomycin $\mathrm{C}$ in the presence of cofactor NADPH. Supercoiled pBR322 DNA $(1.0 \mu \mathrm{g})$ was incubated for 30 minutes at $37^{\circ} \mathrm{C}$ in the presence of P450R $(0.1 \mu \mathrm{g})$, NADPH $(2 \mathrm{mM})$ and mitomycin $\mathrm{C}(100 \mu \mathrm{M})$ with various radical scavengers at indicated concentrations in a final volume of $60 \mu \mathrm{l}$ reaction mixture as described in "Materials and Methods". Agarose gel electrophoresis, lane 1, plasmid DNA + mitomycin C only; lane 2, complete system (plasmid DNA + mitomycin C + P450R + NADPH); lane 3, no P450R control (plasmid DNA + mitomycin C + NADPH); lane 4, no NADPH control (plasmid DNA + mitomycin C + P450R); lane 5, no mitomycin C control (plasmid DNA + P450R + NADPH); lane 6, complete system (plasmid DNA + mitomycin C + P450R + NADPH); lane 7, complete system + SOD (42 units); lane 8, complete system + catalase (42 units); lane 9, complete system + 50 mM DMSO; lane 10, complete system $+10 \mathrm{mM}$ thiourea. SC, supercoiled (form I); OC, open circular (form II).

The effect of increasing drug concentration on the generation of idarubicin- and mitomycin C-induced plasmid DNA strand breaks during their reductive activation by $\mathrm{P} 450$ reductase in the presence of NADPH is shown in Table 3. It was found that at $100 \mu \mathrm{M}$ concentration, both drugs in the presence of sheep lung P450 reductase induced about $40 \%$ increase in DNA scissions over control, while at 200 and $400 \mu \mathrm{M}$ concentrations idarubicin was 20 and $24 \%$ more effective than mitomycin $\mathrm{C}$ in promoting DNA damage (Table 3 ).

The results for the characterization of idarubicin- and mitomycin C-induced DNA damage with respect to increasing enzyme concentration are depicted in Table 4. The extent of idarubicin-induced DNA damage was found to increase with increasing P450 reductase amount up to $0.2 \mu \mathrm{g}$ beyond which saturation occurred, whereas this saturation was reached at a higher amount of $\mathrm{P} 450$ reductase $(1.0 \mu \mathrm{g})$ in the presence of mitomycin C (Table 4).

\section{Idarubicin- and mitomycin C-induced NADPH oxidations by purified $\mathrm{P} 450$ reductases}

The initial rates of idarubicin and mitomycin $\mathrm{C}$ reductions by $\mathrm{P} 450$ reductases purified from phenobarbital-treated rabbit liver, beef liver and sheep lung microsomes were determined by measuring the disappearance of NADPH at $340 \mathrm{~nm}$ as described in detail under
"Materials and Methods". As shown in Table 5, all the purified P450 reductases catalyzed the reduction of idarubicin at about two-fold greater rate than they catalyzed the reduction of mitomycin $\mathrm{C}$. When purified rabbit liver $\mathrm{P} 450$ reductase was used as enzyme source, the specific activities for idarubicin- and mitomycin Cinduced NADPH oxidations were found as 5112 and $2426 \mathrm{nmol} / \mathrm{min} / \mathrm{mg}$ of protein, respectively, which were almost similar to those catalyzed by beef liver P450 reductase. However, sheep lung P40 reductase was found to be somewhat less effective than other $\mathrm{P} 450$ reductases in catalyzing the reduction of both idarubicin and mitomycin $\mathrm{C}$ (Table 5). Table 5 also shows that the specific activities of NADPH-dependent cytochrome $c$ reductions by purified $\mathrm{P} 450$ reductases were found to be similar around $31000 \mathrm{nmol} / \mathrm{min} / \mathrm{mg}$ of purified protein.

\section{DISCUSSION}

Idarubicin is a second-generation anthracycline drug which is clinically effective against breast cancer and some hematological malignancies including acute myelogenous leukemia, multiple myeloma and non-Hodgkin's lymphoma (4-6). Several studies have suggested that bioreductive activation of anthracyclines to free radicals and subsequent redox cycling under aerobic conditions plays an important role in the cytotoxic and genotoxic activity of these agents $(2,8-10)$. 
A

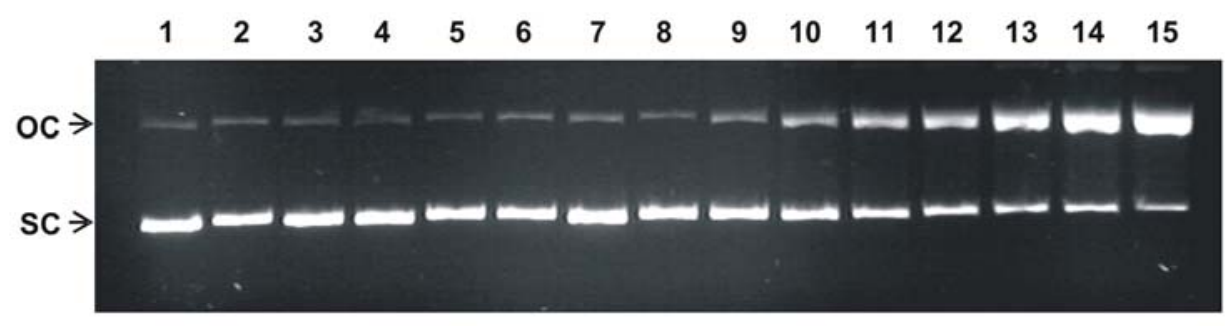

B

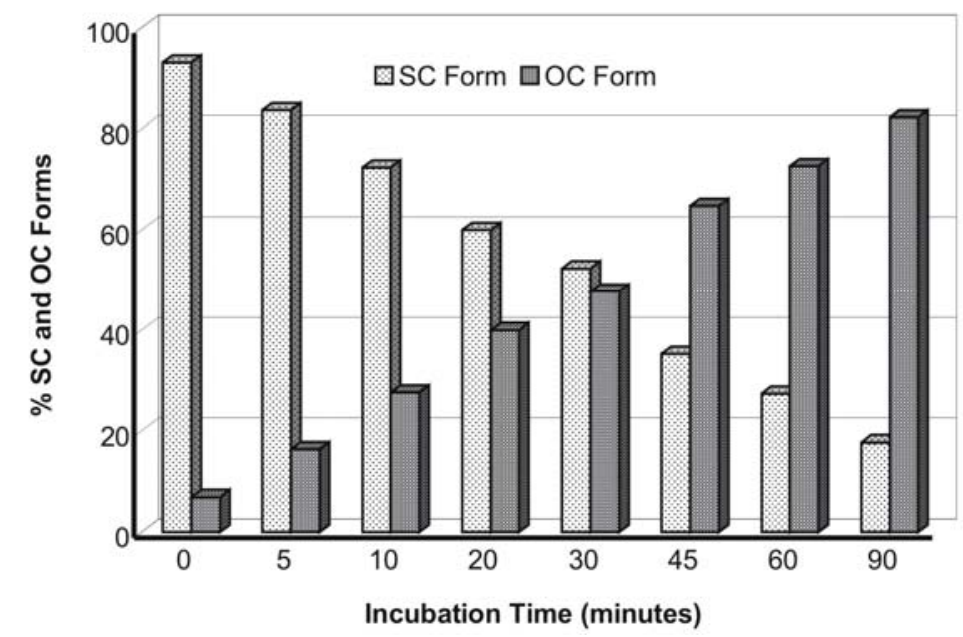

Figure 3. Effect of increasing incubation time on the generation of plasmid DNA strand breaks resulting from purified sheep lung NADPH-cytochrome P450 reductase (P450R)-catalyzed reductive activation of idarubicin in the presence of cofactor NADPH. Supercoiled pBR322 DNA $(1.0 \mu \mathrm{g})$ was incubated for various incubation times $(0-90$ minutes $)$ at $37^{\circ} \mathrm{C}$ in the presence of idarubicin $(100 \mu \mathrm{M})$, NADPH $(2 \mathrm{mM})$ and P450R $(0.1 \mu \mathrm{g})$ in a final volume of $60 \mu \mathrm{l}$ reaction mixture as described in "Materials and Methods". (A) Agarose gel electrophoresis, lane 1, plasmid DNA control; lane 2, plasmid DNA + idarubicin; lane 3, plasmid DNA + NADPH; lane 4, plasmid DNA + P450R; lane 5, no NADPH control (plasmid DNA + P450R + idarubicin); lane 6, no P450R control (plasmid DNA + idarubicin + NADPH); lane 7, no idarubicin control (plasmid DNA + P450R + NADPH); lanes 8 to 15, complete system (plasmid DNA + idarubicin $+\mathrm{P} 450 \mathrm{R}+\mathrm{NADPH})$ incubations for increasing incubation time $(0,5,10,20,30,45,60,90$ minutes, respectively). (B) Percentage of detected SC and OC forms of pBR322 plasmid DNA represented as column chart. Light colored columns represent \% SC form of DNA and dark colored columns represent \% OC form of DNA. Data correspond to lanes 8 to15 (complete system incubations for increasing incubation time; 0, 5, 10, 20, 30, 45, 60, 90 minutes, respectively). SC, supercoiled (form I); OC, open circular (form II).

A large number of cellular oxidoreductases have been shown to catalyze the bioreductive activation of quinone anticancer agents including anthracyclines (see references 2,3 ). To the best of our knowledge, there has been no previous report demonstrating the bioreductive activation of the synthetic anthracycline idarubicin by purified NADPH-cytochrome P450 reductase. Thus, in the present study, for the first time, we showed that purified sheep lung cytochrome $\mathrm{P} 450$ reductase is capable of effectively catalyzing the bioreductive activation of idarubicin to DNA-damaging species. Our results demonstrated that bioreductive activation of idarubicin by purified sheep lung P450 reductase results in the formation of redox active metabolites which causes DNA strand breaks under aerobic conditions through generating ROS. The plasmid DNA experiments with a model compound, mitomycin $\mathrm{C}$, under the same reaction conditions also produced similar results as with idarubicin (see Tables 1-4 and Figures 1 and 2). 


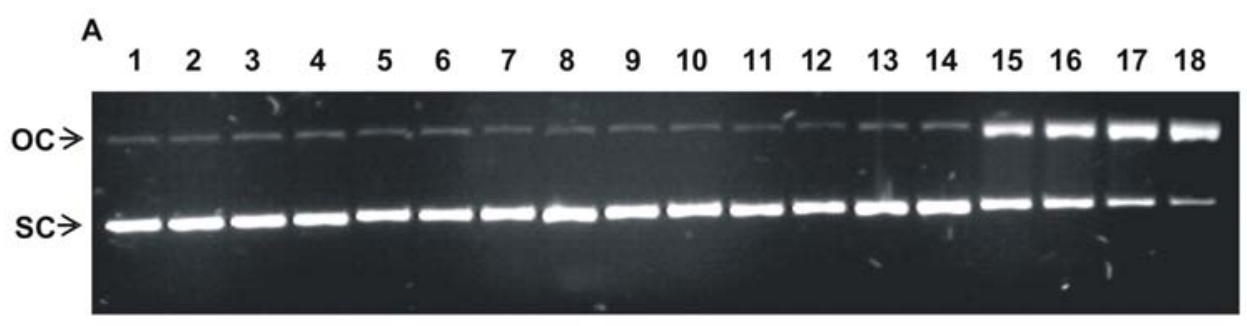

B

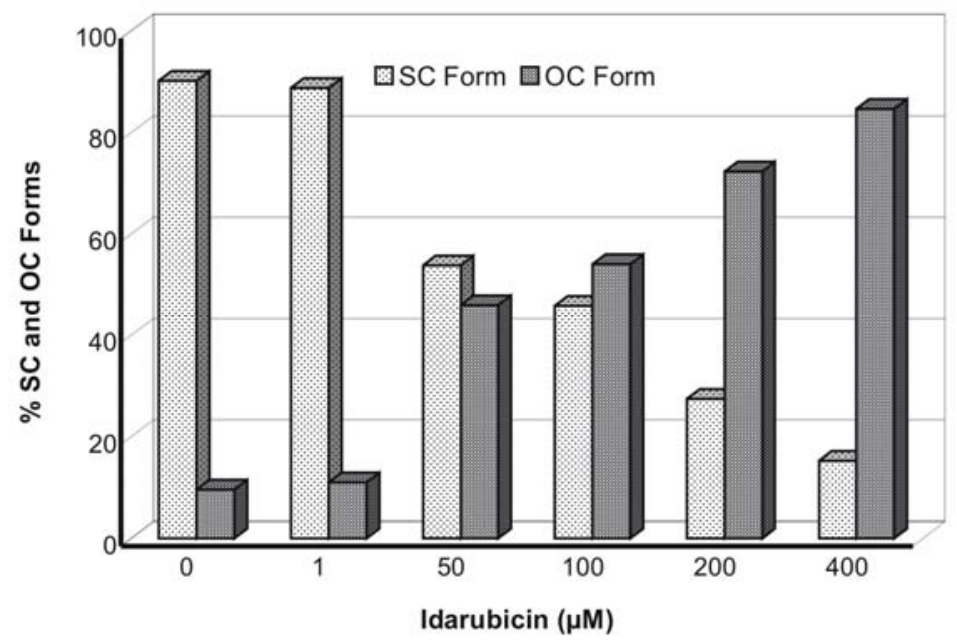

Figure 4. Effect of increasing drug concentration on the generation of plasmid DNA strand breaks resulting from purified sheep lung NADPH-cytochrome P450 reductase (P450R)-catalyzed reductive activation of idarubicin in the presence of cofactor NADPH. Supercoiled pBR322 DNA $(1.0 \mu \mathrm{g})$ was incubated for 30 minutes at $37^{\circ} \mathrm{C}$ in the presence of P450R $(0.1 \mu \mathrm{g})$ and NADPH $(2 \mathrm{mM})$ with various concentrations of idarubicin $(0-400 \mu \mathrm{M})$ in a final volume of $60 \mu \mathrm{l}$ reaction mixture as described in "Materials and Methods". (A) Agarose gel electrophoresis, lane 1, plasmid DNA control; lane 2, plasmid DNA + P450R; lane 3, plasmid DNA + NADPH; lane 4, no idarubicin control (plasmid DNA + P450R + NADPH); lane 5, plasmid DNA + idarubicin; lane 6, no P450R control (plasmid DNA + idarubicin + NADPH); lane 7, no NADPH control (plasmid DNA + P450R + idarubicin); lanes 8 to 12, no NADPH controls for increasing idarubicin concentrations $(1,50,100,200$ and $400 \mu \mathrm{M}$, respectively); lanes 13 to 18 , complete system (plasmid DNA + idarubicin + P450R + NADPH) incubations for increasing idarubicin concentrations $(0,1,50$, 100,200 and $400 \mu \mathrm{M}$, respectively). (B) Percentage of detected SC and OC forms of pBR322 plasmid DNA represented as column chart. Light colored columns represent $\% \mathrm{SC}$ form of DNA and dark colored columns represent $\%$ OC form of DNA. Data correspond to lanes 13 to 18 (complete system incubations for increasing idarubicin concentrations; 0, 1, 50, 100, 200 and $400 \mu \mathrm{M}$, respectively). SC, supercoiled (form I); OC, open circular (form II).

The plasmid DNA experiments and spectrophotometric enzyme assays carried out with purified $\mathrm{P} 450$ reductases revealed that the synthetic anthracycline idarubicin without a methoxy group in the aglycone moiety can undergo bioreductive activation by cytochrome P450 reductase to reactive metabolites like its parent drug daunorubicin. Daunorubicin has been shown previously by others to undergo oneelectron reduction by cytochrome $\mathrm{P} 450$ reductase (28). The structure-activity relationships of anthraquinones are especially important given that their structural differences may influence their ability to undergo bioactivation by flavoenzymes including cytochrome P450 reductase to generate reactive metabolites $(28,29)$.

In plasmid DNA assays, we demonstrated that the purified sheep lung cytochrome P450 reductase can catalyze the formation of DNAdamaging products in the presence of idarubicin as shown by the conversion of supercoiled form into open circular conformation which resulted from the induction of single-strand breaks in DNA. 
A

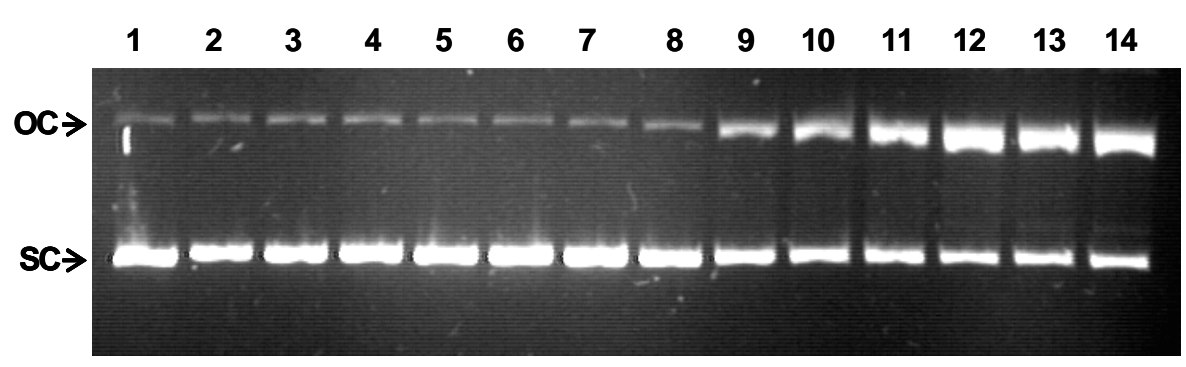

B

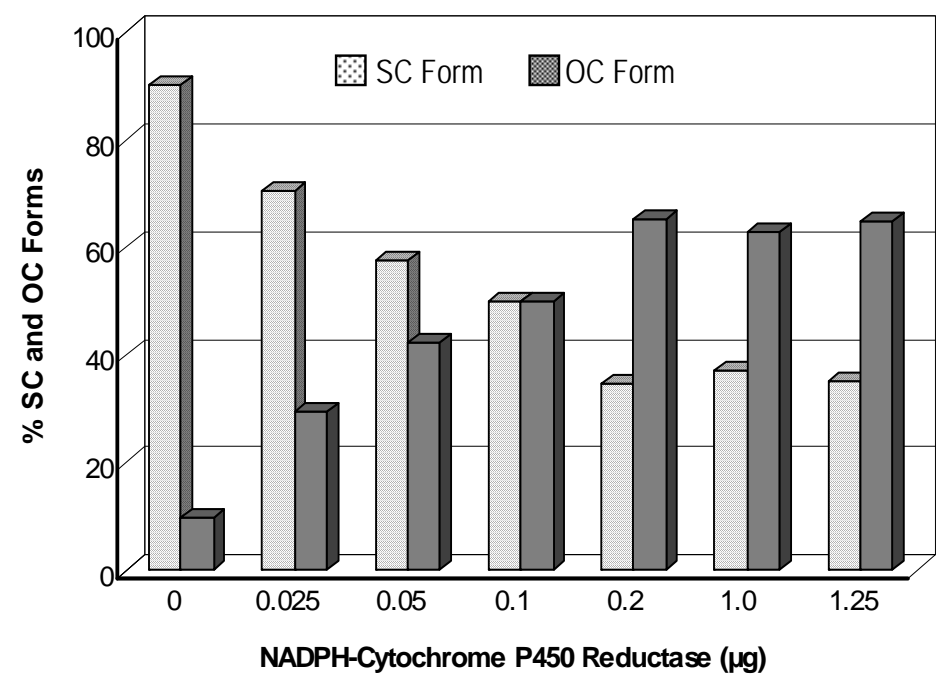

Figure 5. Effect of increasing enzyme concentration on the generation of plasmid DNA strand breaks resulting from purified sheep lung NADPH-cytochrome P450 reductase (P450R)-catalyzed reductive activation of idarubicin in the presence of cofactor NADPH. Supercoiled pBR322 DNA $(1.0 \mu \mathrm{g})$ was incubated for 30 minutes at $37^{\circ} \mathrm{C}$ in the presence of idarubicin $(100 \mu \mathrm{M})$ and NADPH $(2 \mathrm{mM})$ with various concentrations of P450R $(0-1.25 \mu \mathrm{g})$ in a final volume of $60 \mu \mathrm{l}$ reaction mixture as described in "Material and Methods". (A) Agarose gel electrophoresis, lane 1, plasmid DNA control; lanes 2 to 7, no NADPH controls (plasmid DNA + P450R + idarubicin) for increasing P450R concentrations $(0.025,0.050,0.1,0.2,1.0,1.25 \mu \mathrm{g}$, respectively); lanes 8 to 14 , complete system (plasmid DNA + $\mathrm{P} 450 \mathrm{R}+$ idarubicin + NADPH) incubations for increasing P450R concentrations $(0,0.025,0.050,0.1,0.2,1.0,1.25$ $\mu \mathrm{g}$, respectively) including NADPH. (B) Percentage of detected SC and OC forms of pBR322 plasmid DNA represented as column chart. Light colored columns represent $\% \mathrm{SC}$ form of DNA and dark colored columns represent $\%$ OC form of DNA. Data correspond to lanes 8 to 14 (complete system incubations for increasing P450R concentrations, $0,0.025,0.050,0.1,0.2,1.0,1.25 \mu \mathrm{g}$, respectively). SC, supercoiled (form I); OC, open circular (form II).

We used cytochrome P450 reductase purified from sheep lung tissue in these experiments, since previous studies carried out in our laboratory have shown that sheep lung P450 reductase was more resistant to proteolytic cleavage compared to the P450 reductase purified from liver tissue (19). Our findings that antioxidant enzymes SOD and catalase, as well as scavengers of hydroxyl radicals, DMSO and thiourea, offered marked protections against DNA strand breaks generated in the presence of idarubicin, $\mathrm{P} 450$ reductase and cofactor NADPH led us to propose a mechanism for the observed DNA damage induced by idarubicin (Figure 6). 
Table 2. Effect of increasing incubation time on the generation of idarubicin- and mitomycin C-induced plasmid DNA strand breaks in the presence of purified sheep lung NADPH-cytochrome P450 reductase and cofactor NADPH.

\begin{tabular}{|c|c|c|}
\hline \multirow{2}{*}{ Incubation Time (min) } & \multicolumn{2}{|c|}{$\%$ OC-DNA ${ }^{a}$} \\
\hline & Idarubicin-Induced & Mitomycin C-Induced \\
\hline 0 & 6.9 & 8.6 \\
\hline 5 & 16.4 & 20.1 \\
\hline 10 & 27.6 & 30.3 \\
\hline 20 & 40.0 & 43.9 \\
\hline 30 & 47.7 & 52.2 \\
\hline 45 & 64.7 & 62.0 \\
\hline 60 & 72.6 & 70.5 \\
\hline 90 & 82.2 & 82.9 \\
\hline
\end{tabular}

\begin{abstract}
${ }^{a}$ Supercoiled pBR322 DNA $(1.0 \mu \mathrm{g})$ in $100 \mathrm{mM}$ sodium phosphate buffer, $\mathrm{pH} 7.4$, was incubated for various incubation times $\left(0-90\right.$ minutes) at $37^{\circ} \mathrm{C}$ in the presence of either drug $(100 \mu \mathrm{M})$, NADPH $(2 \mathrm{mM})$ and purified sheep lung cytochrome P450 reductase $(0.1 \mu \mathrm{g})$ in a final volume of $60 \mu \mathrm{l}$ reaction mixture and subjected to agarose gel electrophoresis. Gels were photographed and the amount of DNA damage was quantified. \% OC-DNA was calculated as described in "Materials and Methods". OC, open circular (form II).
\end{abstract}

Table 3. Effect of increasing drug concentration on the generation of idarubicin- and mitomycin C-induced plasmid DNA strand breaks in the presence of purified sheep lung NADPH-cytochrome P450 reductase and cofactor NADPH.

\begin{tabular}{|c|c|c|}
\hline \multirow{2}{*}{ Drug Concentration $(\mu \mathrm{M})$} & \multicolumn{2}{|c|}{$\%$ OC-DNA ${ }^{\mathrm{a}}$} \\
\hline & Idarubicin-Induced & Mitomycin C-Induced \\
\hline 0 & 9.7 & 9.4 \\
\hline 1 & 11.1 & 12.4 \\
\hline 50 & 46.1 & 40.6 \\
\hline 100 & 54.1 & 48.3 \\
\hline 200 & 72.4 & 52.7 \\
\hline 400 & 84.7 & 60.9 \\
\hline
\end{tabular}

\footnotetext{
${ }^{\text {a }}$ Supercoiled pBR322 DNA $(1.0 \mu \mathrm{g})$ in $100 \mathrm{mM}$ sodium phosphate buffer, pH 7.4, was incubated for 30 minutes at $37^{\circ} \mathrm{C}$ in the presence of purified sheep lung cytochrome $\mathrm{P} 450$ reductase $(0.1 \mu \mathrm{g})$ and NADPH $(2 \mathrm{mM})$ with various concentrations of either drug $(0-400$ $\mu \mathrm{M})$ in a final volume of $60 \mu \mathrm{l}$ reaction mixture and subjected to agarose gel electrophoresis. Gels were photographed and the amount of DNA damage was quantified. $\%$ OC-DNA was calculated as described in "Materials and Methods". OC, open circular (form II).
}

This mechanism involves that one-electron reductive activation of idarubicin by purified $\mathrm{P} 450$ reductase under aerobic conditions results in the formation of corresponding semiquinone radical which undergoes redox cycling with molecular oxygen to generate superoxide. The
$\mathrm{O}_{2}{ }^{--}$formed by this process could then undergo spontaneous or enzymatic dismutation to produce hydrogen peroxide $\left(\mathrm{H}_{2} \mathrm{O}_{2}\right)$ which in the presence of trace amounts of ferric ions rapidly decomposes to very reactive hydroxyl radical via Fenton reaction. 
Table 4. Effect of increasing enzyme concentration on the generation of idarubicin- and mitomycin C-induced plasmid DNA strand breaks in the presence of purified sheep lung NADPH-cytochrome P450 reductase and cofactor NADPH.

\begin{tabular}{|c|c|c|}
\hline \multirow{2}{*}{$\begin{array}{c}\text { NADPH-Cytochrome P450 } \\
\text { Reductase Amount ( } \mu \mathrm{g})\end{array}$} & \multicolumn{2}{|c|}{$\%$ OC-DNA ${ }^{\mathrm{a}}$} \\
\hline & Idarubicin-Induced & Mitomycin C-Induced \\
\hline 0 & 9.7 & 14.9 \\
\hline 0.025 & 29.6 & 32.2 \\
\hline 0.05 & 42.2 & 38.8 \\
\hline 0.1 & 50.1 & 46.1 \\
\hline 0.2 & 65.3 & 54.1 \\
\hline 1.0 & 63.0 & 71.9 \\
\hline 1.25 & 64.9 & 69.6 \\
\hline
\end{tabular}

${ }^{\text {a }}$ Supercoiled pBR322 DNA $(1.0 \mu \mathrm{g})$ in $100 \mathrm{mM}$ sodium phosphate buffer, $\mathrm{pH} 7.4$, was incubated for 30 minutes at $37^{\circ} \mathrm{C}$ in the presence of either drug $(100 \mu \mathrm{M})$ and NADPH $(2$ $\mathrm{mM})$ with various concentrations of purified sheep lung cytochrome P450 reductase (0$1.25 \mu \mathrm{g})$ in a final volume of $60 \mu \mathrm{l}$ reaction mixture and subjected to agarose gel electrophoresis. Gels were photographed and the amount of DNA damage was quantified. $\%$ OC-DNA was calculated as described in "Materials and Methods". OC, open circular (form II).

Table 5. Idarubicin- and mitomycin C-induced NADPH oxidations by NADPH-cytochrome P450 reductases purified from phenobarbital-treated rabbit liver, beef liver and sheep lung microsomes.

\begin{tabular}{|c|c|c|c|}
\hline \multirow{2}{*}{ Purified Enzyme Source } & \multirow{2}{*}{$\begin{array}{c}\text { Cytochrome } c \\
\text { Reduction }^{\mathrm{a}} \\
\left(\mathrm{nmol} \mathrm{min}^{-1} \mathrm{mg}^{-1}\right)\end{array}$} & \multicolumn{2}{|c|}{$\begin{array}{l}\text { NADPH Oxidationb } \\
\left(\text { (nmol } \text { min }^{-1} \mathrm{mg}^{-1}\right)\end{array}$} \\
\hline & & $\begin{array}{l}\text { Idarubicin- } \\
\text { Induced }\end{array}$ & $\begin{array}{l}\text { Mitomycin C- } \\
\text { Induced }\end{array}$ \\
\hline Rabbit Liver P450 Reductase & 31735.6 & 5112.2 & 2425.7 \\
\hline Beef Liver P450 Reductase & 30891.7 & 5673.9 & 2452.8 \\
\hline Sheep Lung P450 Reductase & 31087.3 & 3111.7 & 1461.6 \\
\hline
\end{tabular}

Experimental conditions for each enzyme activity determination are described in detail under "Materials and Methods". Data represent the averages of duplicate determinations.

${ }^{\text {a }} \mathrm{NADPH}$-dependent cytochrome $c$ reductase activities were assayed at $25^{\circ} \mathrm{C}$ in $0.3 \mathrm{M}$ potassium phosphate buffer, $\mathrm{pH} 7.7$.

${ }^{b}$ The reaction mixture contained $0.3 \mathrm{M}$ potassium phosphate buffer, $\mathrm{pH} 7.7,0.1 \mathrm{mM}$ EDTA, pH 7.7, idarubicin $(25 \mu \mathrm{M})$ or mitomycin $\mathrm{C}(25 \mu \mathrm{M})$, appropriate amounts of purified cytochrome $\mathrm{P} 450$ reductases and $0.1 \mathrm{mM} \mathrm{NADPH}$ in a final volume of $1.0 \mathrm{ml}$ at $25^{\circ} \mathrm{C}$.

The highly potent $\mathrm{OH}^{*}$ then causes the formation of DNA strand breaks $(11,30,31)$. The plasmid DNA experiments using mitomycin $\mathrm{C}$, a model redox cycling quinone with cytochrome $\mathrm{P} 450$ reductase, also confirmed that the mechanism of DNA damage by idarubicin appears to involve its redox cycling with cytochrome $\mathrm{P} 450$ reductase under aerobic conditions to generate ROS.
The idarubicin concentrations used in our plasmid DNA experiments were higher than its clinically achievable concentrations. However, for example in the case of doxorubicin, several studies have shown that ROS could be detected also at very low concentrations of this drug in cancer cells (for details see the review 2). 


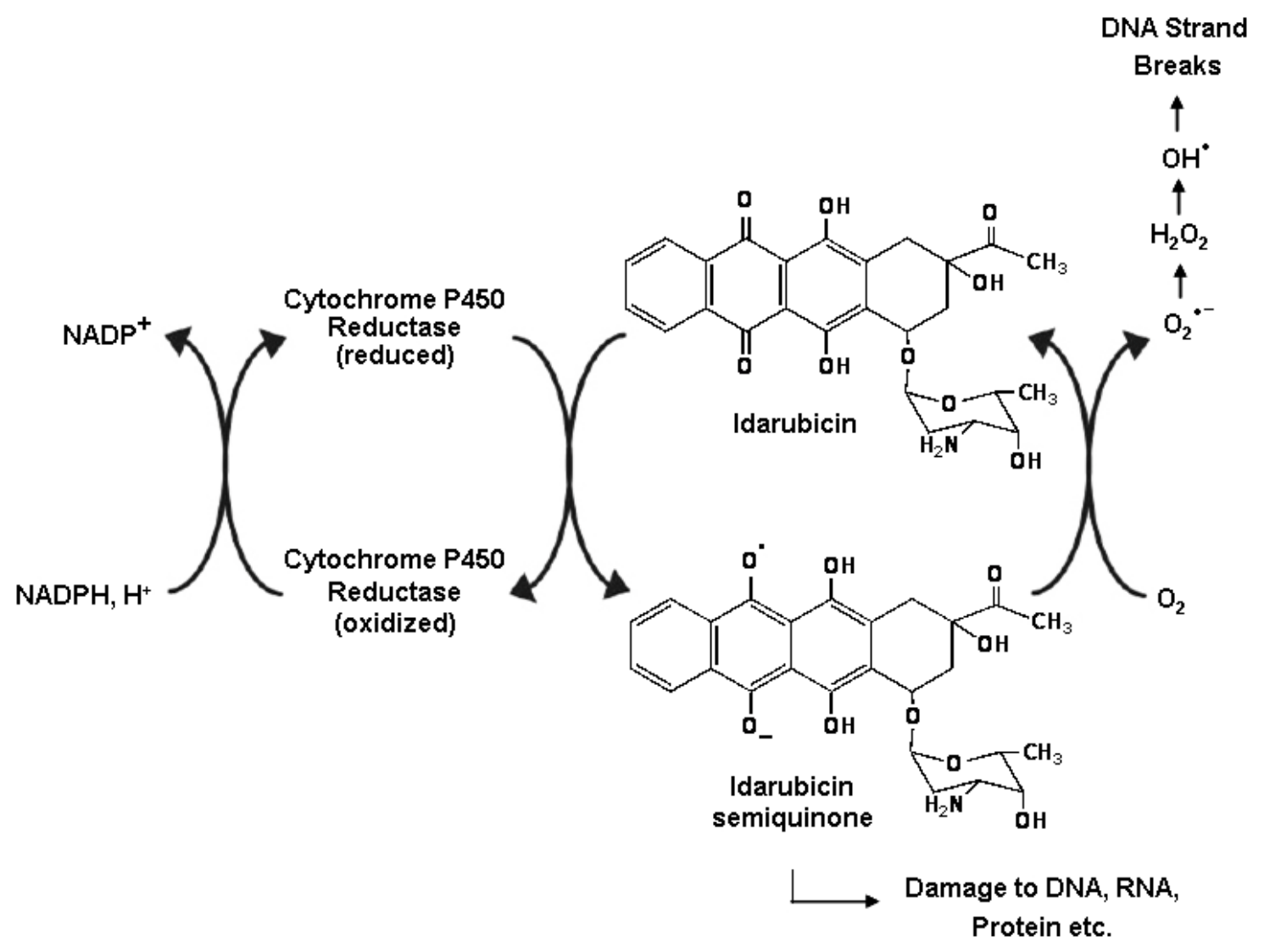

Figure 6. The mechanism of idarubicin-induced DNA damage in the presence of NADPH-cytochrome P450 reductase and cofactor NADPH.

Thus, it may be suggested based on these results that ROS generated during cytochrome P450 reductase-catalyzed reductive activation of idarubicin may contribute both to the chemotherapeutic effects of idarubicin in the treatment of tumor cells as well as its toxic side effects in normal healthy cells. The ROS formed in the presence of cytochrome P450 reductase may also be responsible for the genotoxic effects of this antineoplastic drug to induce secondary malignancies.

When the potential of idarubicin to induce DNA damage was compared with that of mitomycin $\mathrm{C}$ at varying incubation times and drug concentrations as well as at different enzyme amounts, it was shown that both drugs exhibited almost similar DNA-damaging potentials under aerobic conditions (see Tables 2-4). The only marked difference observed was the greater ability of idarubicin to induce DNA strand breaks at higher drug concentrations (200 and $400 \mu \mathrm{M})$ compared to mitomycin $\mathrm{C}$ (Table 3). This finding may suggest that these structurally related compounds might have similar abilities to redox cycle with cytochrome P450 reductase, and thus to induce single-strand breaks in DNA.

The enzyme assay experiments with $\mathrm{P} 450$ reductases purified from phenobarbital-treated rabbit liver, beef liver and sheep lung microsomes revealed that idarubicin exhibited about two-fold higher rate of reduction, as measured by NADPH oxidation at $340 \mathrm{~nm}$, than mitomycin $\mathrm{C}$ by all the purified P450 reductases (Table 5). The rate of superoxide radical production by these drugs is expected to be proportional to their one-electron reduction rates by cytochrome $\mathrm{P} 450$ reductase. Thus, based on these results, idarubicin seems to be a more cytotoxic drug than mitomycin $\mathrm{C}$ in terms of the generation of reactive and/or redox active metabolites by P450 reductase. However, despite the two-fold difference in their reduction rates, the reason for observing no major difference in the DNA-damaging potentials of idarubicin and mitomycin $\mathrm{C}$ at various incubation 
conditions in plasmid DNA experiments remains unclear and needs further detailed investigation. This may be related to the sensitivity of the plasmid DNA damage assay or to the differences in the assay conditions. Nevertheless, the differences in the reduction rates of idarubicin and mitomycin $\mathrm{C}$ by purified sheep lung P450 reductase may account for the increased ability of idarubicin to induce DNA strand breaks at higher drug concentrations (200 and $400 \mu \mathrm{M})$ compared to mitomycin $\mathrm{C}$. Another point is that the purified sheep lung $\mathrm{P} 40$ reductase, when compared to P450 reductases purified from beef liver and phenobarbital-treated rabbit liver microsomes, was found to be somewhat less effective in catalyzing the reduction of both idarubicin and mitomycin $\mathrm{C}$ (Table 5). This functional difference may be caused by the differences in threedimensional structures of $\mathrm{P} 450$ reductases purified from different species that occur as a result of differences in amino acid sequences (for the reviews, see references 32-34).

The present study has conclusively demonstrated that NADPH-cytochrome P450 reductase effectively catalyzes the bioreductive activation of idarubicin to DNA-damaging species with the resulting formation of DNA strand breaks under aerobic conditions. These results implicated this pathway as one of the mode of idarubicin action potentially contributing to its antitumor effect. The results of the present study may also suggest that cytochrome P450 reductases may potentially be used as therapeutic agent on their own in cancer treatment strategies or their genes, in gene-directed enzyme prodrug therapy (GDEPT) strategy in combination with bioreductive anticancer drugs like mitomycin $\mathrm{C}$ and idarubicin $(35,36)$.

\section{ACKNOWLEDGEMENTS}

This study was supported by The Scientific and Technological Research Council of Turkey Research Project Fund (Project number: 106T139) and Middle East Technical University Research Project Fund (Project number: BAP-0811-DPT-2002K120510).

\section{REFERENCES}

[1]. Minotti, G., Menna, P., Salvatorelli, E., Cairo, G., Gianni, L., Anthracyclines: molecular advances and pharmacologic developments in antitumor activity and cardiotoxicity. Pharmacol Rev, 56:185-229, 2004.

[2]. Doroshow, J.H., Anthracyclines and Anthracenediones, in: Chabner BA: Longo DL (eds), Cancer Chemotherapy and Biotherapy: Principles and Practices. Lippincott Williams and Wilkins, Philadelphia, PA, pp 415-450, 2006.

[3]. Powis, G., Metabolism and reactions of quinoid anticancer agents. Pharmacol Ther, 35:57-162, 1987.

[4]. Borchmann, P., Hübel, K., Schnell, R., Engert, A., Idarubicin: a brief overview on pharmacology and clinical use. Int $\mathrm{J}$ Clin Pharmacol Ther, 35:80-83, 1997.

[5]. Crivellari, D., Lombardi, D., Spazzapan, S., Veronesi, A., Toffoli, G., New oral drugs in older patients: a review of idarubicin in elderly patients. Crit Rev Oncol Hematol, 49:153-163, 2004.

[6]. Goebel, M., Oral idarubicin - an anthracycline derivative with unique properties. Ann Hematol, 66:33-43, 1993.

[7]. Gewirtz, D.A., A critical evaluation of the mechanisms of action proposed for the antitumor effects of the anthracycline antibiotics adriamycin and daunorubicin. Biochem Pharmacol, 57:727-741, 1999.

[8]. Sinha, B.K., Free radicals in antitumor drug pharmacology. Chem Biol Interact, 69:293317, 1989.

[9]. Powis, G., Free radical formation by antitumor quinones. Free Radic Biol Med, 6:63-101, 1989.

[10]. Taatjes, D.J., Gaudiano, G., Resign, K., Koch, T.H., Redox pathway leading to the alkylation of DNA by the anthracycline, antitumor drugs adriamycin and daunomycin. J Med Chem, 40:1276-1286, 1997.

[11]. Kappus, H., Overview of enzyme systems involved in bioreduction of drugs and in redox cycling. Biochem Pharmacol, 35:1-6, 1986.

[12]. Fisher, G.R., Gutierrez, P.L., Free radical formation and DNA strand breakage during metabolism of diaziquone by $\mathrm{NAD}(\mathrm{P}) \mathrm{H}$ quinone-acceptor oxidoreductase (DTdiaphorase) and NADPH cytochrome $c$ reductase. Free Radic Biol Med, 11:597-607, 1991.

[13]. Shen, T., Hollenberg, P.F., The mechanism of stimulation of NADPH oxidation during the mechanism-based inactivation of cytochrome P450 2B1 by N-methylcarbazole: redox cycling and DNA scission. Chem Res Toxicol 7:231-238, 1994.

[14]. Kumagai, Y., Tsurutani, Y., Shinyashiki, M., Homma-Takeda, S., Nakai, Y., Yoshikawa, 
T., Shimojo, N., Bioactivation of lapachol responsible for DNA scission by NADPHcytochrome P450 reductase. Environ Toxicol Pharmacol, 3:245-250, 1997.

[15]. Garner, A.P., Paine, M.J.I., RodriguezCrespo, I., Chinje, E.C., Ortiz De Montellano, P., Stratford, I.J., Tew, D.G., Wolf, C.R., Nitric oxide synthases catalyze the activation of redox cycling and bioreductive anticancer agents. Cancer Res, 59:1929-1934, 1999.

[16]. Çelik, H., Arinç, E., Bioactivation of mitomycin $\mathrm{C}$ responsible for formation of "ROS" and DNA scission by lung cytochrome P450 reductase. FEBS J, 273(Suppl. 1):160, 2006.

[17]. Çelik, H., Arinç, E., Comparison of the in vitro DNA-damaging potential of the two anticancer drugs idarubicin and mitomycin $\mathrm{C}$ in the presence of NADPH-cytochrome P450 reductase. Drug Metab Rev, 38 (Suppl. 1):185-186, 2006.

[18]. Adali, O., Arinç, E., Electrophoretic, spectral, catalytic and immunochemical properties of highly purified cytochrome P-450 from sheep lung. Int J Biochem, 22:1433-1444, 1990.

[19]. Işcan, M.Y., Arinç, E., Comparison of highly purified sheep liver and lung NADPHcytochrome $\mathrm{P}-450$ reductases by the analysis of kinetic and catalytic properties. Int J Biochem, 20:1189-1196, 1988.

[20]. Sen, A., Arinç, E., Purification and characterization of cytochrome P450 reductase from liver microsomes of feral leaping mullet (Liza saliens). J Biochem Mol Toxicol, 12:103-113, 1998.

[21]. Arinç, E., Çelik, H., Biochemical characteristics of purified beef liver NADPHcytochrome $\mathrm{P} 450$ reductase. J Biochem Mol Toxicol, 16:286-297, 2002.

[22]. Laemmli, U.K., Cleavage of structural proteins during the assembly of the head of bacteriophage T4. Nature, 227:680-685, 1970.

[23]. Lowry, O.H., Rosebrough, N.J., Farr, A.L., Randall, R.J., Protein measurement with the Folin phenol reagent. J Biol Chem, 193:265275, 1951.

[24]. Masters, B.S.S., Williams, C.H., Kamin, H., The preparation and properties of microsomal TPNH-cytochrome $c$ reductase from pig liver. Methods Enzymol, 10:565-573, 1967.

[25]. Yonetani, T., Studies on cytochrome $c$ peroxidase. II. Stoichiometry between enzyme, $\mathrm{H}_{2} \mathrm{O}_{2}$ and ferrocytochrome $c$ and enzymic determination of extinction coefficients of cytochrome $c$. J Biol Chem, 240:4509-4514, 1965.

[26]. Ashikaga, T., Wada, M., Kobayashi, H., Mori, M., Katsumura, Y., Fukui, H., Kato, S.,
Yamaguchi, M., Takamatsu, T., Effect of the photocatalytic activity of $\mathrm{TiO}_{2}$ on plasmid DNA. Mutat Res, 466:1-7, 2000.

[27]. Seow, H.A., Penketh, P.G., Baumann, R.P., Sartorelli, A.C., Bioactivation and resistance to mitomycin C. Methods Enzymol, 382:221233, 2004.

[28]. Pawlowska, J., Tarasiuk, J., Wolf, C.R., Paine, M.J.I., Borowski, E., Differential ability of cytostatics from anthraquinone group to generate free radicals in three enzymatic systems: NADH dehydrogenase, NADPH cytochrome P450 reductase and xanthine oxidase. Oncol Res, 13:245-252, 2003.

[29]. Tarasiuk, J., Garnier-Suillerot, A., Stefanska, B., Borowski, E., The essential role of anthraquinones as substrates for NADH dehydrogenases in their redox cycling activity. Anticancer Drug Des, 7:329-340, 1992.

[30]. Brawn, K., Fridovich, I., DNA strand scission by enzymatically generated oxygen radicals. Arch Biochem Biophys, 206:414-419, 1981.

[31]. Kovacic, P., Osuna, J.A. Jr., Mechanisms of anti-cancer agents: emphasis on oxidative stress and electron transfer. Curr Pharm Des, 6:277-309, 2000.

[32]. Lu, A.Y.H., NADPH-Dependent Cytochrome P450 Reductase, in: Arinç E: Schenkman JB: Hodgson E (eds), Molecular Aspects of Monooxygenases and Bioactivation of Toxic Compounds. Plenum Press, New York, NY, pp 135-147, 1991.

[33]. Shen, A., Kasper, C.B., Protein and Gene Structure and Regulation of NADPHCytochrome P450 Reductase, in: Schenkman JB: Greim H (eds), Handbook of Experimental Pharmacology. Springer-Verlag Press, New York, NY, pp 35-59, 1993.

[34]. Gutierrez, A., Grunau, A., Paine, M., Munro, A.W., Wolf, C.R., Roberts, G.C., Scrutton, N.S., Electron transfer in human cytochrome P450 reductase. Biochem Soc Trans, 31:497501, 2003.

[35]. Cowen , R.L., Garside, E.J., Fitzpatrick, B., Papadopoulou, M.V., Williams, K.J., Gene therapy approaches to enhance bioreductive drug treatment. Br J Rad, 81:S45-S56, 2008.

[36]. Altaner C., Prodrug cancer gene therapy. Cancer Letters, 270:191-201, 2008. 